\title{
Taxonomic Consideration of Microbacterium lacticum, Microbacterium flavum, and Microbacterium thermosphactum
}

\author{
D. L. COLLINS-THOMPSON, T. SøRHAUG, L. D. WITTER, and Z. J. ORDAL \\ Departments of Food Science and Microbiology, University of Illinois, Urbana, \\ Illinois 61801
}

\begin{abstract}
Classification of the microbacteria in a separate genus, Microbacterium Orla-Jensen, has been rejected by some authors. In this study three strains of Microbacterium lacticum Orla-Jensen, the type species of the genus, one strain of Microbacterium flavum Orla-Jensen, and two strains of Microbacterium thermosphactum McLean and Sulzbacher were examined with the hope that the somewhat precarious taxonomic position of these species might be clarified. Included in this examination were: the determination of deoxyribonucleic acid (DNA) base composition by the thermal denaturation technique, the development of protein and esterase profiles by polyacrylamide gel electrophoresis, and selected enzyme assays associated with the Embden-Meyerhof, hexosemonophosphate, and tricarboxylic acid pathways. The DNA base ratio studies showed $M$. thermosphactum to have a per cent guanine plus cytosine content of 36 compared with 58 for $M$. flavum and 64 for $M$. lacticum. The enzyme assays also indicated heterogeneity. All possessed enzymes associated with the EmbdenMeyerhof and the hexosemonophosphate pathways, but $M$. thermosphactum alone failed to yield enzymatic evidence for an operational tricarboxylic acid cycle. Also, only $M$. flavum showed evidence of a glyoxylate shunt. Protein profiles and esterase patterns were also sufficiently different to suggest a separation of $M$. thermosphactum from $M$. lacticum and $M$. flavum. These studies furnish additional evidence that $M$. flavum be placed in the genus Corynebacterium Lehmann and Neumann 1896. $M$. thermosphactum is an unusual organism which does not appear to be assignable to any of the presently recognized families of bacteria. The placement of $M$. lacticum in the genus Corynebacterium Lehmann and Neumann 1896 would render Microbacterium Orla-Jensen 1919 a later, subjective synonym of Corynebacterium. M. lacticum does possess characteristics not unlike those of the plant pathogenic corynebacteria.
\end{abstract}

The validity of the genus Microbacterium has been questioned ever since its origination by Orla-Jensen (26) in 1919. The grouping of the microbacteria by Orla-Jensen on the basis of size and heat resistance has never been a satisfactory one. The validity of this genus was initially questioned by Wittern (38). A major portion of her investigation dealt with the taxonomic position of $M$. mesentericum OrlaJensen, which she assigned to the genus Mycobacterium Lehmann and Neumann. Jensen (13) concluded that $M$. lacticum OrlaJensen and $M$. liquefaciens Orla-Jensen be placed in the genus Corynebacterium Lehmann and Neumann. Studies by Jensen (14) with $M$. flavum Orla-Jensen led him to the conclusion that this organism was actually a mycobacterium. Work by Speck (34), Orla-Jensen (27), and Doetsch and Pelczar (9) indicated a very close relationship of the microbacteria with the genera Corynebacterium, Propionibacterium, and Lactobacillus. The genus Microbacterium has been placed in several different families and currently is in the family Corynebacteriaceae (3). With the isolation of $M$. thermosphactum by McLean and Sulzbacher (22), further confusion was added to the taxonomy of the microbacteria. Several authors have tried to 
evaluate or justify the present location of this genus and have added much information in attempts to clarify the present situation $(5-8$, $30,33,35$ ).

It is apparent that conflicting opinions exist concerning the systematic position of these organisms. In this study deoxyribonucleic acid (DNA) base ratios have been applied because such values are considered useful taxonomic aids. Comparative biochemical pathways, protein patterns, and esterase patterns have also been utilized to present data that may be of some significance in evaluating the taxonomic position of the genus Microbacterium.

\section{MATERIALS AND METHODS}

Strains used. The following organisms were used: $M$. thermosphactum ATCC 11509 and I24 (isolated in this laboratory); $M$. flavum ATCC 10340 and 0J8; $M$. lacticum ATCC 8180, CC10 and 359-M1. Cultures of strains $0 \mathrm{~J} 8$, CC10, and 359-M1 were kindly provided by J. J. Iandolo.

These organisms were cultured in Trypticase soy broth (TSB, Baltimore Biological Laboratory) at either $22 \mathrm{C}$ (M. thermosphactum) or $32 \mathrm{C} \mathrm{(M.} \mathrm{flavum} \mathrm{and} M$. lacticum). Stock cultures ( $1 \%$ inoculum) were maintained in TSB at $-20 \mathrm{C}$. For the study of tricarboxylic acid cycle enzymes and the glyoxylate shunt system, the organisms were grown in a medium of the same composition as TSB except that glucose was replaced by $0.2 \%$ succinate.

Preparation of cells and cell-free extracts. All cultures were harvested in the late logarithmic phase of growth by centrifugation at $2 \mathrm{C}$, washed twice with $0.01 \mathrm{M}$ tris(hydroxymethyl)aminomethane (Tris)hydrochloride buffer ( $p H$ 7.2), and resuspended in the same buffer. Cell-free extracts were prepared by multiple passes through a French pressure cell at 8,000 psi. The cell debris was removed by centrifugation at $15,000 \times \mathrm{g}$ for $30 \mathrm{~min}$ at $2 \mathrm{C}$. The cell-free extracts were either used immediately or stored at $-20 \mathrm{C}$.

Isolation of DNA and determination of melting curves. The isolation of DNA was achieved by the method of Marmur (23). To obtain complete lysis with the sodium lauryl sulfate treatment, strains of $M$. lacticum and $M$. thermosphactum were heated for 20 min at $65 \mathrm{C}$ and those of $M$. flavum were heated for $15 \mathrm{~min}$ at $60 \mathrm{C}$. After isolation and purification of the DNA, the purified material was dissolved in a solution containing $0.15 \mathrm{M}$ sodium chloride and $0.15 \mathrm{M}$ sodium citrate (SSC) or in a 1:10 dilution of the SSC solution depending on the expected melting point. The melting curves for the DNA were obtained by using a Bausch \& Lomb Spectronic 505 spectrophotometer. Temperature was controlled by a Lauda K2 thermostat circulator connected to the cell holder. Thermocouples were used to measure rise in temperature. The content of DNA was regulated to give a starting optical density of 0.50 at $260 \mathrm{~nm}$. The adjustment procedure (when using 1:10 dilution of SSC) to standardize all values to the SSC level was used (10).
Polyacrylamide gel electrophoresis for protein and esterase staining. The gel electrophoresis procedure was previously described by Collins-Thompson et al. (4) except that the gel contained $0.08 \% N, N, N^{\prime}$, $N^{\prime}$-tetramethyl ethylenediamine and $0.08 \%$ ammonium persulfate.

Protein profiles. Protein fractions in the gel were stained for $30 \mathrm{~min}$ in an aqueous solution containing $50 \%$ methyl alcohol, $1.0 \%$ glacial acetic acid, and $0.05 \%$ amido black. Destaining of the gel was achieved by repeated washing in $10 \%$ glacial acetic acid on a shaker. The finished gels were scanned at $600 \mathrm{~nm}$ with a Gilford gel scanning attachment to a Beckman DU spectrophotometer converted with a photomultiplier connected to a Sargent model SR recorder.

Esterase patterns. The zymogram technique of Hunter and Markert (12) and Allen (1) was used for esterase activity, except that the staining buffer was replaced by $0.12 \mathrm{M}$ Tris-hydrochloride $(p \mathrm{H} \mathrm{7.2)}$ and $3 \%$ acetone was used to aid in the staining procedure. Four naphthyl esters were used: acetate, propionate, butyrate, and caproate. Staining was allowed to proceed for $1 \mathrm{hr}$, whereupon the gels were washed in water and scanned at $600 \mathrm{~nm}$ in a manner similar to that used for the protein stains.

TABLE 1. Bibliography of procedures used for the assay of selected enzymes

Enzyme Reference

Hexokinase (EC 2.7.11) ............ (20)

Fructose diphosphate

aldolase (EC 4.1.2.13)

Glucose-6-phosphate de-

hydrogenase (EC 1.1.1.49) . . . . . . . . (20)

Phosphogluconate dehy-

drogenase (EC 1.1.1.43)

Lactate dehydrogenase

(EC 1.1.1.27) .....

Reduced NAD oxidase

(EC 1.6.99.3) . . . . .

Reduced NADP oxidase

(EC 1.6.99.1) .

Citrate synthetase

(EC 4.1.3.7) ....

Aconitate hydratase

(EC 4.2.1.3) . . . . . .

Isocitrate dehydrogenase

(NADP) (EC 1.1.1.42)

Threo-D -isocitrate $^{-}$

glyoxylate lyase

(EC 4.1.3.1) ......

Oxoglutarate dehydro-

genase (EC 1.2.4.2) .

Succinyl-CoA synthetase

(EC 6.2.1.5) ........

Succinate dehydrogenase

(EC 1.3.99.1) ....

Fumarate hydratase

(EC 4.2.1.2) .....
Malate dehydrogenase

(EC 1.1.1.37) ... . 
Enzyme assays. Whenever possible, enzyme activities were determined spectrophotometerically by using a pyridine nucleotide-dependent system and a total volume of $3 \mathrm{ml}$ in each cuvette. A unit of enzyme activity was defined as that amount of enzyme catalyzing the formation of $1 \mu$ mole of product per $\min$. Specific activity was expressed as units of enzyme per milligram of protein. The protein contents of cell-free extracts were determined by the biuret method (31). Crystalline serum albumin was used for the standard curve. The enzymes assayed and the references to the procedures used are listed in Table 1 .

\section{RESULTS AND DISCUSSION}

The DNA base compositions, expressed as moles per cent of guanine plus cytosine of the moles of total base (\% GC), were determined for the test organisms by the $50 \%$ denaturation

TABLE 2. Thermal denaturation of DNA from species of Microbacterium

\begin{tabular}{|c|c|c|c|}
\hline Organism & $\mathrm{T}_{\mathrm{m}}(\mathrm{SSC})^{a}$ & $\mathrm{~T}_{\mathrm{m}}(0.1 \mathrm{SSC})$ & $\% \mathrm{GC}$ \\
\hline 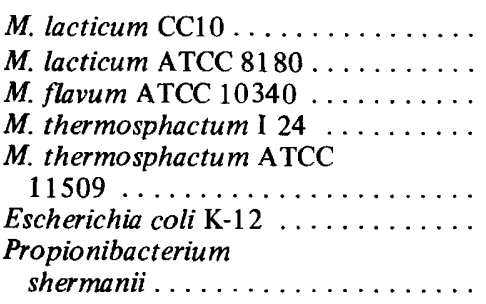 & $\begin{array}{l}95.6^{b} \\
95.1^{b} \\
93.2^{b} \\
84.1^{b} \\
84.1 \\
89.7 \\
96.5^{c}\end{array}$ & $\begin{array}{l}80.6 \\
80.1 \\
78.2\end{array}$ & $\begin{array}{l}64.1 \\
62.9 \\
58.2 \\
36.1 \\
\\
36.1 \\
49.8 \\
\\
66.3\end{array}$ \\
\hline
\end{tabular}

${ }^{a} \mathrm{~T}_{\mathrm{m}}$ (SSC): value for $50 \%$ melting of DNA in $0.15 \mathrm{M}$ sodium chloride, $0.15 \mathrm{M}$ sodium citrate.

$b$ Projected values based on the $E$. coli standard.

$c$ This value taken from the literature.

TABLE 3. Specific activities of selected enzymes assayed from cell-free extracts of three species of Microbacterium

\begin{tabular}{|c|c|c|c|}
\hline \multirow[b]{2}{*}{ Enzy me } & \multicolumn{3}{|c|}{ Specific activity $^{a}$} \\
\hline & $\begin{array}{c}M . \\
\text { lacticum } \\
\mathrm{CC} 10\end{array}$ & $\begin{array}{c}\text { M. } \\
\text { flavum } \\
\text { OJ8 }\end{array}$ & $\begin{array}{c}M . \\
\text { thermosphactum } \\
\text { I24 }\end{array}$ \\
\hline Hexokinase $^{b}$ & 0.026 & 0.041 & 0.396 \\
\hline $\begin{array}{c}\text { Fructose diphosphate } \\
\text { aldolase }{ }^{b} \ldots \ldots \ldots\end{array}$ & 0.014 & 0.046 & 0.389 \\
\hline Glucose-6-phosphate & & & \\
\hline dehydrogenase $^{b} \ldots$ & 0.010 & 0.010 & 0.115 \\
\hline $\begin{array}{c}\text { 6-phosphogluconate } \\
\text { dehydrogenase }^{b}\end{array}$ & 0.067 & 0.019 & 0.279 \\
\hline Lactate dehydrogenase $b$ & 0.050 & 0.037 & 0.433 \\
\hline Reduced NAD oxidase ... & 0.073 & 0.092 & 0.010 \\
\hline Reduced NADP oxidase $\ldots \ldots \ldots \ldots$ & 0 & 0.01 & 0 \\
\hline Citrate synthetase $\ldots \ldots \ldots \ldots \ldots$ & 0.030 & 0.054 & 0 \\
\hline Aconitate hydratase ..... & 0.059 & 0.109 & 0 \\
\hline Isocitrate dehydrogenase . . . & 0.114 & 0 & 0 \\
\hline Isocitrate ly ase (EC 4.1.3.1) & 0 & 0.320 & 0 \\
\hline Oxoglutarate dehydrogenase & 0 & 0 & 0 \\
\hline Succinyl-CoA synthetase . . . . . . & 0.035 & 0 & 0 \\
\hline Succinate dehydrogenase $\ldots \ldots \ldots \ldots$ & 0.010 & 0.050 & 0 \\
\hline Fumarate hydratase $\ldots \ldots \ldots \ldots$ & 0.072 & 0.075 & 0.002 \\
\hline Malate dehydrogenase $\ldots \ldots \ldots \ldots$ & 0.314 & 0.478 & 0.002 \\
\hline
\end{tabular}

${ }^{a}$ Expressed as micromoles of substrate transformed per minute per milligram of protein.

$b$ Cells grown in TSB (Trypticase soy broth). Otherwise grown in a medium of the same composition as TSB except glucose was replaced by $0.2 \%$ succinate. 
point $\left(\mathrm{T}_{m}\right)$ method. These results are given in Table 2. Included as reference standards are the values for Escherichia coli and Propionibacterium shermanii, which agree within $1 \%$ with values in the literature. The heterogeneity of the genus Microbacterium is certainly indicated by the \% GC values obtained. $M$. thermosphactum, with a \% GC of 36 , coincides with the streptococci (\% GC: $34-42 \%$ ); $M$. lacticum, with a $\%$ GC of 64 , corresponds with the arthrobacters (\% GC: $60-64 \%$ ) and is just slightly different from the corynebacteria (\% GC: $48-59 \%$ ); $M$. flavum, with a $\%$ GC of 58 , corresponds with the corynebacteria.

The specific activities of selected enzymes from cultures of the test organisms are given in Table 3. The most noticeable results in Table 3 are the general similarity of the enzyme complement in $M$. lacticum and $M$. flavum, which are quite different in this respect from $M$. thermosphactum. $M$. thermosphactum showed a high activity in the catabolism of glucose to lactic acid, a characteristic of the lactic acid bacteria. Also, those enzymes associated with the tricarboxylic acid cycle were almost totally absent. Both $M$. lacticum and $M$. flavum showed lower activity in glucose catabolism to lactic acid, but the tricarboxylic acid cycle enzymes were present. The presence and high activity of isocitrate lyase in $M$. flavum

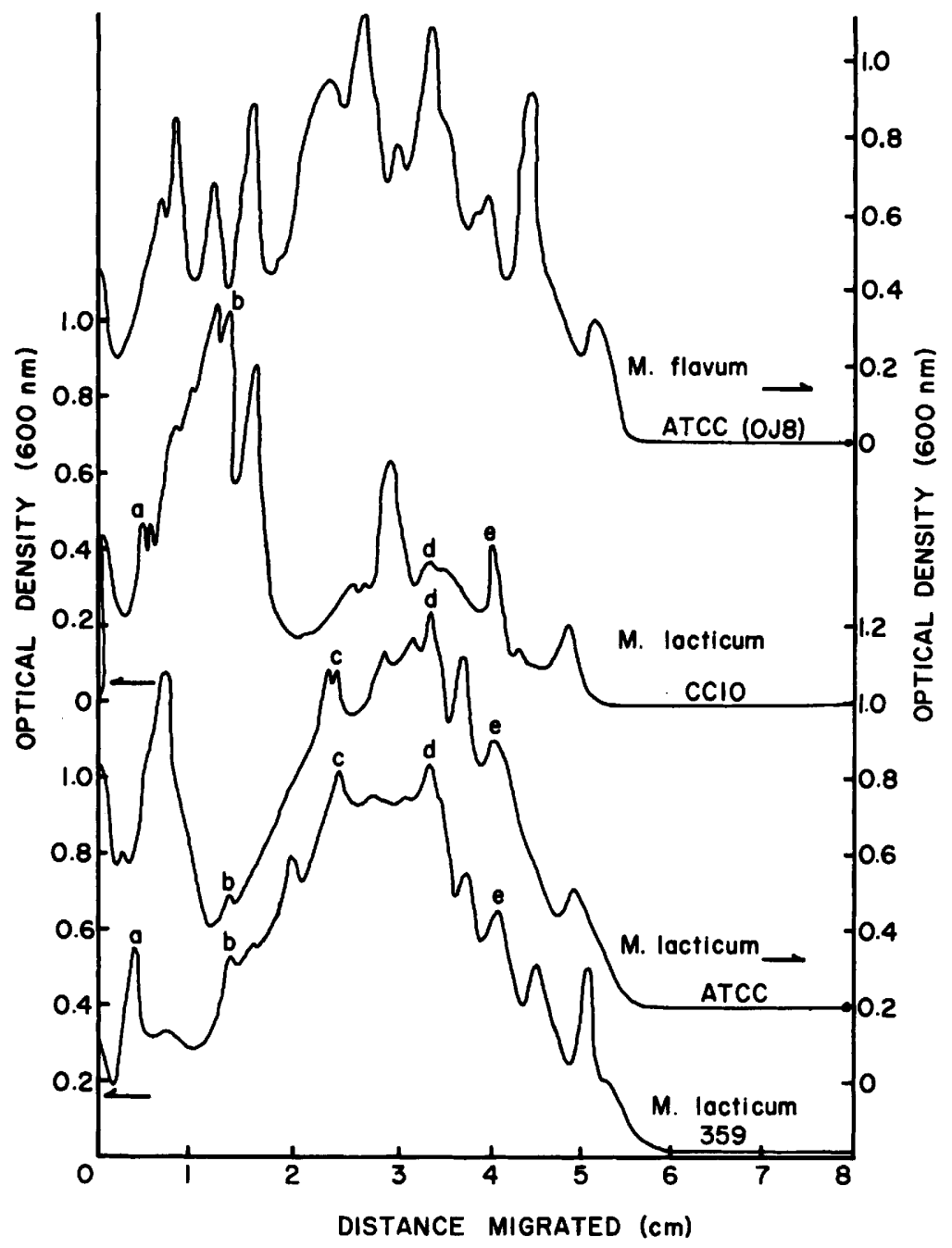

FIG. 1. Protein profiles of cell-free extracts of Microbacterium flavum and $M$. lacticum after separation by polyacrylamide gel electrophoresis and staining with amido black. 
indicated a glyoxylate shunt pathway, which has also been shown to be present in the corynebacteria (18). The absence of oxoglutarate dehydrogenase activity in these organisms is a condition that is similar to that found in many bacteria that degrade sugar without the formation of carbon dioxide.

It has been suggested (24) that the protein and enzyme profiles developed from electrophoretic separation in gels might show promise in distinguishing bacterial species. Protein profiles of $M$. lacticum and $M$. flavum are given in Fig. 1, and those of $M$. thermosphactum and Lactobacillus brevis are given in Fig. 2. L. brevis was included simply as a standard for our separation method, but it does provide the profile of an organism not in the genus being investigated.

It was hoped that the protein profiles obtained in this investigation would (i) be easily interpreted, (ii) show no significant difference between strains of a given species, (iii) show a definite but modest difference between the closely related species, $M$. lacticum and $M$. flavum, and (iv) show a substantial difference between $M$. thermosphactum and the other two species of Microbacterium. None of these hopes was very conclusively realized except that the $M$. thermosphactum strains had a protein profile substantially different from that of either $M$. lacticum or $M$. flavum, which were also substantially different from one another. The protein profiles did, however, show the heterogeneity of these Microbacterium species.

Comparison of the esterases of $M$. lacticum, $M$. thermosphactum, and $M$. flavum ( $L$. brevis was again included as a standard for the separation procedure) on four substrates is given in Table 4 . Both strains and species varied in both the location of esterase bands and in

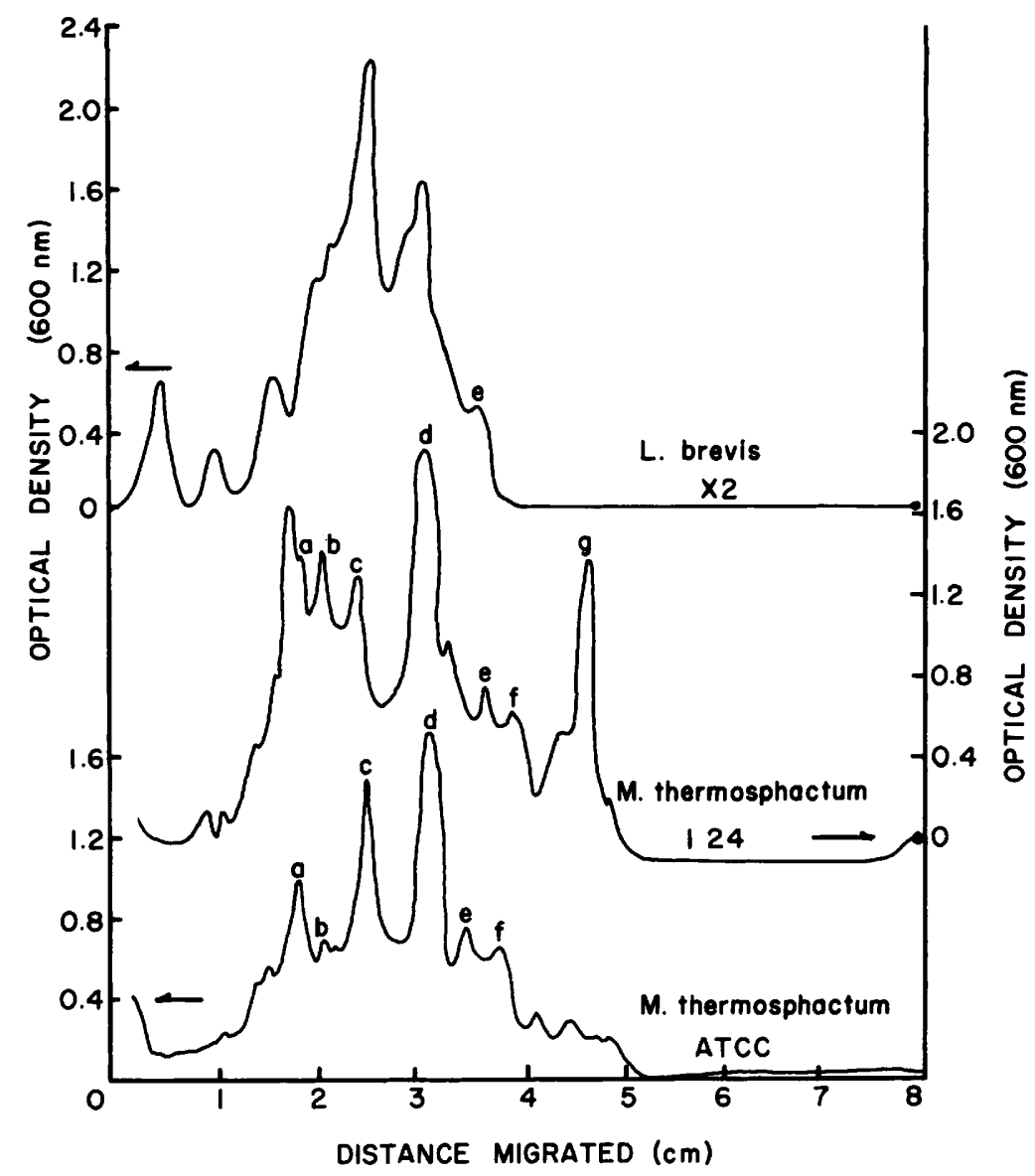

FIG. 2. Protein profiles of cell-free extracts of Microbacterium thermosphactum and Lactobacillus brevis after separation by polyacrylamide gel electrophoresis and staining with amido black. 
TABLE 4. Migration distance and intensity of esterase bands developed by polyacrylamide gel electrophoresis of cell-free extracts of strains of three species of Microbacterium and one of Lactobacillus

\begin{tabular}{|c|c|c|c|c|c|}
\hline \multirow[b]{2}{*}{ Strain } & \multirow[b]{2}{*}{$\begin{array}{l}\text { Distance } \\
\text { travelled } \\
(\mathrm{mm})\end{array}$} & \multicolumn{4}{|c|}{ Band intensity ${ }^{\alpha}$ of $\alpha$-naphthylester of: } \\
\hline & & Acetate & Propionate & Butyrate & Caproate \\
\hline $\begin{array}{l}\text { Lactoba- } \\
\quad \text { cillus } \\
\quad \text { brevis X2 }\end{array}$ & $\begin{array}{l}18 \\
24 \\
41 \\
45\end{array}$ & $\begin{array}{c}+ \\
++ \\
- \\
-\end{array}$ & $\begin{array}{c}++ \\
++ \\
+ \\
-\end{array}$ & $\begin{array}{c}+++ \\
+++ \\
+ \\
-\end{array}$ & $\begin{array}{l}- \\
+ \\
+ \\
+\end{array}$ \\
\hline $\begin{array}{l}\text { Micro- } \\
\text { bacterium } \\
\text { flavum ATCC } 10340\end{array}$ & $\begin{array}{l}17 \\
36 \\
49 \\
53\end{array}$ & $\begin{array}{c}++ \\
+ \\
+ \\
+\end{array}$ & $\begin{array}{l}+ \\
+ \\
+ \\
+\end{array}$ & $\begin{array}{l}+ \\
+ \\
+ \\
+\end{array}$ & $\begin{array}{l}- \\
- \\
- \\
-\end{array}$ \\
\hline $\begin{array}{l}\text { M. ther- } \\
\text { mosphactum ATCC } \\
11159\end{array}$ & $\begin{array}{l}13 \\
20 \\
32 \\
44\end{array}$ & $\begin{array}{c}++ \\
+++ \\
+++ \\
++\end{array}$ & $\begin{array}{l}* \\
* \\
* \\
*\end{array}$ & $\begin{array}{l}* \\
* \\
* \\
*\end{array}$ & $\begin{array}{l}* \\
* \\
* \\
*\end{array}$ \\
\hline $\begin{array}{l}\text { M. ther- } \\
\text { mosphactum } 124\end{array}$ & $\begin{array}{l}12 \\
34 \\
46 \\
67\end{array}$ & $\begin{array}{c}+ \\
- \\
+++ \\
+\end{array}$ & $\begin{array}{c}+ \\
++ \\
++ \\
+\end{array}$ & $\begin{array}{c}- \\
+ \\
+++ \\
-\end{array}$ & $\begin{array}{l}- \\
+ \\
+ \\
-\end{array}$ \\
\hline $\begin{array}{l}\text { M. lacti- } \\
\text { cum ATCC } 8180\end{array}$ & $\begin{array}{l}35 \\
42 \\
45 \\
62\end{array}$ & $\begin{array}{c}+ \\
+++ \\
+++ \\
+\end{array}$ & $\begin{array}{c}++ \\
+++ \\
+++ \\
+++\end{array}$ & $\begin{array}{c}+ \\
+++ \\
+ \\
-\end{array}$ & $\begin{array}{l}- \\
+ \\
- \\
-\end{array}$ \\
\hline $\begin{array}{l}\text { M. lacti- } \\
\quad \text { cum } 359 \mathrm{M}-1\end{array}$ & $\begin{array}{l}10 \\
22 \\
42 \\
45 \\
51\end{array}$ & $\begin{array}{c}+ \\
+ \\
+++ \\
+++ \\
++\end{array}$ & $\begin{array}{c}+ \\
+ \\
++ \\
++ \\
+\end{array}$ & $\begin{array}{l}- \\
+ \\
+ \\
+ \\
+\end{array}$ & $\begin{array}{l}- \\
+ \\
+ \\
+ \\
+\end{array}$ \\
\hline
\end{tabular}

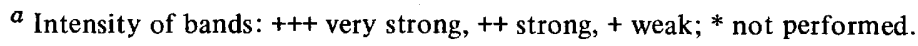

their intensity. Again the esterase profiles serve only to show the heterogeneity of this group.

Apparently it has been proposed that the genus Microbacterium be eliminated from the forthcoming edition of Bergey's Manual. M. flavum will then be transferred to the genus Corynebacterium and $M$. thermosphactum will be assigned to an appendix group of organisms which are not readily classifiable (M. Rogosa, personal communication).
Both the DNA base ratio and the metabolism of $M$. flavum correspond with those of corynebacteria. This additional information and the well established similarities already reported in the literature (30) substantiate the transfer of $M$. flavum to the genus Corynebacterium.

$M$. lacticum has an unfamiliar cell wall murein pattern like that of the plant pathogenic corynebacteria (32). The GC percentage obtained in this study, 63, is somewhat higher 
than that for the genus Corynebacterium (48-59\%). Another source reports a $M$. lacticum strain with a \% GC of 69.3 (39); however, both strains in the present study were consistently lower. Both $M$. lacticum and $M$. flavum come from dairy sources, and, although $M$. lacticum is the more heat-resistant, the heat resistance of $M$. flavum far exceeds that of most bacteria (3, 6). Both have a deficient tricarboxylic acid cycle but deviate in the glyoxylate shunt, and with minor differences they coincide in other classical characteristics $(3,6)$. It is open to question whether $M$. lacticum should also be classified in the genus Corynebacterium, but this arrangement seems just as valid as to maintain it in the convenient genus Microbacterium. The transfer of $M$. lacticum, the type species of the genus Microbacterium, to the genus Corynebacterium would render Microbacterium Orla-Jensen 1919 a later, subjective synonym of Corynebacterium Lehmann and Neumann 1896.

Taxonomically speaking, there is little compelling need to keep $M$. thermosphactum together with $M$. lacticum and $M$. flavum. The former is primarily associated with meat products, not dairy products, is not thermoduric, and grows readily at refrigeration temperatures. The \% GC of $M$. thermosphactum coincides with that of the lactic acid bacteria, particularly the streptococci, and is substantially below that of the corynebacteria. However, $M$. thermosphactum is catalase-positive, and Shaw and Stead (33) reported that the lipid composition is incompatible with that of the Lactobacillaceae. The presence of DL-diaminopimelic acid in the cell walls of $M$. thermosphactum (32) suggested a greater similarity with the Corynebacteriaceae than with the Lactobacillaceae. Thus, it appears that $M$. thermosphactum cannot be comfortably placed in any of the presently accepted families of bacteria.

\section{ACKNOWLEDGMENTS}

We wish to acknowledge the technical assistance of Gloria Vaaler.

T. S. acknowledges support from the Agricultural Research Council of Norway.

\section{LITERATURE CITED}

1. Allen, S. L. 1961. Genetic control of the esterases in the protozoan Tetrahymena pyriformis. Ann. N. Y. Acad. Sci. 94: 753-773.

2. Anfinsen, C. B. 1955. Aconitase from pig heart muscle, p. 695-698. In S. P. Colowick and N. O. Kaplan (ed.), Methods in enzymology, vol. 1. Academic Press Inc., New York.

3. Breed, R. S., E. G. D. Murray, and N. T. Smith. 1957. Bergey's manual of determinative bacterology, 7 th ed. Williams and Wilkins, Baltimore, Md.

4. Collins-Thompson, D. L., T. Sørhaug, L. D. Witter, and Z. J. Ordal. 1971. Glycerol ester hydrolase activity of Microbacterium thermosphactum. Appl. Microbiol. 21: 9-12.

5. Davidson, C. M., and E. F. Hartree. 1968. Cytochrome as a guide to classifying bacteria: taxonomy of Microbacterium thermosphactum. Nature (London) 220: 502-504.

6. Davidson, C. M., P. Mobbs, and J. M. Stubbs, 1968. Some morphological and physiological properties of Microbacterium thermosphactum. J. Appl. Bacteriol. 31: 551-559.

7. Davis, G. H. G., L. Fomin, E. Wilson, and K. G. Newton. 1969. Numerical taxonomy of Listeria, streptococci and possibly related bacteria. J. Gen. Microbiol. 57: 333-348.

8. Davis, G. H. G., and K. G. Newton. 1969 Numerical taxonomy of some coryneform bacteria. J. Gen. Microbiol. 56: 195-214.

9. Doetsch, R. N., and M. J. Pelczar, Jr. 1948. The microbacteria. I. Morphological and physiological characteristics. J. Bacteriol. 56: 37-49.

10. Hill, L. R. 1968. The determination of deoxyribonucleic acid base composition and its application to bacterial taxonomy, p. 177-186. In B. M. Gibbs, and D. A. Shapton (ed.), Identification methods for microbiologists, series 2B. Academic Press Inc., New York.

11. Hill, R. L., and R. A. Bradshaw. 1969. Fumarase, p. 91-99. In J. M. Lowenstein (ed.), Methods in enzymology, vol. 13. Academic Press Inc., New York.

12. Hunter, R. L., and C. L. Markert. 1957. Histochemical demonstration of enzymes separated by zone electrophoresis in starch gels. Science 125: 1294-1 295.

13. Jensen, H. L. 1932. Contributions to our knowledge of the Actinomycetales. IV. The identity of certain species of Mycobacterium and Proactinomyces. Proc. Linnean Soc. N. S. W. 57: 364-367.

14. Jensen, H. L. 1934. Studies on saprophytic mycobacteria and corynebacteria. Proc. Linnean Soc. N. S. W. 59: 19-61.

15. Keddie, R. M., G. S. B. Leask, and J. M. Grainzer. 1966. A comparison of coryneform bacteria from soil and herbage: cell wall composition and nutrition. J. Appl. Bacteriol. 29: 17-43.

16. Kitto, G. B. 1969. Intra- and extra-mitochondrial malate dehydrogenase from chicken and tuna heart, p. 106-116. In J. M. Lowenstein (ed.). Methods in enzymology, vol. 13. Academic Press Inc., New York.

17. Kornberg, A. 1955. Lactate dehydrogenase of muscle, p. 441-443. In S. P. Colowick and N. O. Kaplan (ed). Methods in enzymology, vol. 1. Academic Press Inc., New York.

18. Kornberg, M. L. 1966. Anaplerotic sequences and their role in metabolism. In P. N. Campbell and G. 
D. Greville (ed.) Essays in biochemistry, vol. 2. Academic Press Inc., New York.

19. Khouw, B. T., and M. D. McCurdy. 1969. Tricarboxylic acid cycle enzymes and morphogenesis in Blastocladiella emersonii. J. Bacteriol. 99: 197-205.

20. Lee, C. K., and Z. J. Ordal, 1967. Regulation effect of pyruvate on the glucose metabolism of Clostridium thermosaccharolyticum. J. Bacteriol. 94: 530-536.

21. McFadden, B. A. 1969. Isocitrate lyase, p. 163-170. In J. M. Lowenstein (ed.), Methods in enzymology, vol. 13. Academic Press Inc., New York.

22. McLean, R. A., and W. L. Sulzbacher. 1953. Microbacterium thermosphactum, spec nov; a nonheat resistent bacterium from fresh pork sausage. J. Bacteriol. 65: 428-433.

23. Marmur, J. 1961. A procedure for the isolation of deoxyribonucleic acid from microorganisms. J. Mol. Biol. 3: 208-218.

24. Norris, J. R. 1968. The application of gel electrophoresis to the classification of micro-organisms, p. 49-56. In Chemotaxonomy and serotaxonomy. Academic Press Inc., New York.

25. O'Brian, R. W., and J. R. Stern. 1969. Requirement for sodium in the anaerobic growth of Aerobacter aerogenes on citrate. J. Bacteriol. 98: 388-393.

26. Orla-Jensen, S. 1919. The lactic acid bacteria. Copenhagen, Denmark.

27. Orla-Jensen, S. 1943. Die echten Milchasäurebakterien. Munksgaard, Copenhagen.

28. Ramaley, R. F., W. A. Bridger, R. W. Moyer, and P. D. Boyer. 1967. The preparation properties and reactions of succinyl coenzyme-a synthetase and its phosphorylated form. J. Biol. Chem. 242: 4287-4298.

29. Reed, L. J., and B. B. Mukerjee. 1969. Ketoglutarate dehydrogenase complex in Escherichia coli, p. 55-61. In J. M. Lowenstein (ed.), Methods in enzymology, vol. 13. Academic Press Inc., New York.

30. Robinson, K. 1966. Some observations on the taxonomy of the genus Microbacterium. II. Cell wall analysis, gel electrophoresis and serology. $\mathbf{J}$. Appl. Bacteriol. 29: 616-624.

31. Robinson, M. W., and G. G. Hogden. 1940. The biuret reaction in the determination of serum proteins. I. A study of the conditions necessary for the production of a stable color which bears a quantitative relationship to the protein concentration. J. Biol. Chem. 135: 707-725.

32. Schleifer, K. H. 1970. Die Mureintypen in der Gattung Microbacterium. Arch. Mikrobiol. 71: 271-282.

33. Shaw, N., and D. Stead. 1970. A study of the lipid composition of Microbacterium thermosphactum as a guide to its taxonomy. J. Appl. Bacteriol. 33: 470-473.

34. Speck, M. L. 1943. The genus Microbacterium. J. Dairy Sci. 26: 533-543.

35. Vandemark, P. J., and W. A. Wood. 1956. The pathways of glucose dissimilation by Microbacterium lacticum. J. Bacteriol. 71: 385-392.

36. von Tigerstrom, M., and J. J. R. Campbell. 1966. The accumulation of ketoglutarate by suspensions of Pseudomonas aeruginosa. Can. J. Microbiol. 12: $1005-1013$.

37. Weitzman, P. D. J. 1969. Citrate synthetase from E. coli, p. 22-26. In J. M. Lowenstein (ed.), Methods in enzymology, vol 13. Academic Press Inc., New York.

38. Wittern, A. 1933. Beitrage zur Kenntnis der "Mikrobakterien." Orla-Jensen. Zentralbl. Bakteriol. Parasitenk. Infektionsk. Hyg. Abt. 2 87: 412-446.

39. Yamada, K., and K. Komagata. 1970. Taxonomic studies on coryneform bacteria. III. DNA base composition of coryneform bacteria. J. Gen. Appl. Microbiol. 16: 215-224. 